\title{
Peningkatan Kualitas Lingkungan Daerah Aliran Sungai Solo Berbasis Interactive Participation
}

\author{
Rr Diah Nugraheni Setyowati \\ Fakultas Sains dan Teknologi, Universitas Islam Negeri Sunan Ampel \\ e-mail :diahnugraheni@uinsby.ac.id
}

\begin{abstract}
The river has a strategic role as a buffer for people's lives, so that the quality of the river affects surrounding environment. The development in various fields were changes in land use and environmental damage that caused a decrease in the hydrological function of watershed and decrease in environmental quality. The decline in environmental quality has not received special attention from both the government and the surrounding community, therefore an effort to improve quality of the environment based on interactive participation is needed. The method used in this research is descriptive qualitative, so that in the analysis of problems and making models which are the final results of the study will be based on qualitative analysis. The research phase starts from the identification of the problem, then continues the process of collecting primary and secondary data. After the data is fulfilled, an analysis process is carried out which results in a simple design of an interactive participation based community empowerment model. Based on the results of data analysis, the Solo DAS is in a critical condition, where the conditions describe the number of hydrological disasters that occurred. Land use in Solo watershed has changed, currently land is dominated by rice fields (irrigation and rainfed), gardens, fields and settlements. The maximum daily rainfall in Solo watershed is around $73-186 \mathrm{~mm} /$ day, supported by relatively flat landforms, so it can be concluded that the Solo watershed is a flood-prone area. From the results of data analysis it was also found that the higher the level of education, the higher the level of awareness in maintaining and improving the quality of the environment. The level of community education in the Solo DAS is quite good, so that appropriate community empowerment is interactive participation. The great opportunity for the community to be directly involved shows that the appropriate model of interactive participation empowerment is the Bottom Up model.
\end{abstract}

Keywords : Watershed, Quality, Environment, Interactive Participation, Society

\begin{abstract}
ABSTRAK
Sungai memiliki peranan strategis sebagai penyangga kehidupan masyarakat, sehingga kualitas sungai mempengaruhi lingkungan sekitarnya. Namun seiring dengan perkembangan pembangunan di berbagai bidang, terjadilah perubahan tata guna lahan dan kerusakan lingkungan yang menyebabkan penurunan fungsi hidrologis daerah aliran sungai dan penurunan kualitas lingkungan. Penurunan kualitas lingkungan kurang mendapat perhatian khusus baik dari pemerintah maupun masyarakat sekitarnya, oleh karena itu perlu adanya upaya peningkatan kualitas lingkungan berbasis interactive participation. Metode yang digunakan dalam penelitian ini bersifat deskriptif kualitatif, sehingga dalam analisis permasalahan dan pembuatan model yang merupakan hasil akhir penelitian akan didasarkan pada analisis kualitatif. Tahap penelitian dimulai dari identifikasi masalah, kemudian dilanjutkan proses pengumpulan data primer dan data sekunder. Setelah data terpenuhi, dilakukan proses analisis yang menghasilkan sebuah rancangan sederhana mengenai model pemberdayaan masyarakat berbasis interactive participation. Berdasar hasil analisa data, DAS Solo berada pada kondisi kritis, dimana kondisi tersebut menggambarkan banyaknya bencana hidrologis yang terjadi. Pemanfaatan lahan di DAS Solo mengalami perubahan, saat ini lahan didominasi sawah (irigasi dan tadah hujan), kebun, tegalan dan permukiman penduduk. Curah hujan maksimum harian
\end{abstract}


DAS Solo sekitar $73 \mathrm{~mm} / \mathrm{hari}$ - $186 \mathrm{~mm} /$ hari, didukung oleh bentuk lahan yang relatif datar, sehingga dapat disimpulkan bahwa DAS Solo termasuk daerah rawan banjir. Dari hasil analisis data juga diperoleh bahwa semakin tinggi tingkat pendidikan maka semakin tinggi tingkat kesadaran dalam menjaga dan meningkatkan kualitas lingkungan. Tingkat pendidikan masyarakat di DAS Solo cukup baik, sehingga pemberdayaan masyarakat yang sesuai adalah interactive participation. Besarnya kesempatan masyarakat untuk terlibat langsung menunjukkan bahwa model pemberdayaan interactive participation yang sesuai adalah model Bottom Up.

Kata kunci : Daerah Aliran Sungai, Kualitas, Lingkungan, Partisipasi Interaktif, Masyarakat

\section{PENDAHULUAN}

\section{Latar Belakang}

Sungai memiliki peranan strategis sebagai penyangga kehidupan masyarakat, sehingga kualitas sungai mempengaruhi kualitas lingkungan sekitarnya. Sungai dan anak-anak sungai berada di dalam suatu wilayah yang sering kita sebut sebagai Daerah Aliran Sungai (DAS). Berikut ini adalah gambar Daerah Aliran Sungai (DAS).

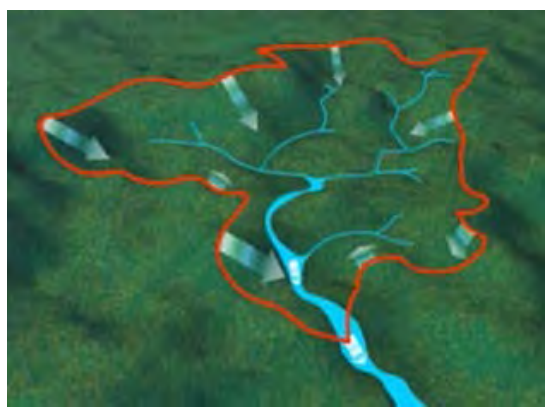

Gambar 1.1. Daerah Aliran Sungai

Pada umumnya daerah aliran sungai didefinisikan sebagai wilayah / kawasan yang membentang luas, dimana bentangannya dibatasi oleh punggungpunggung bukit sekaligus sebagai pembatas topografi wilayah / kawasan tersebut. DAS merupakan suatu ekosistem dimana terdapat unsur-unsur lingkungan fisik, nonfisik maupun biofisik, serta unsur-unsur kimia yang berinteraksi secara dinamis sehingga terdapat keseimbangan didalamnya. Keberadaan daerah aliran sungai secara yuridis formal tertuang dalam Peraturan
Pemerintah No.33 Tahun 1970 tentang Perencanaan Hutan [1].

DAS mempunyai kemampuan menyimpan air dan menjaga Namun seiring dengan perkembangan pembangunan di berbagai bidang, diantaranya bidang kehutanan, bidang industri, bidang pertanian dan perkebunan, bidang perikanan, bidang permukiman, drastisnya perubahan tata guna lahan, serta eksploitasi sumber daya alam yang berlebihan, maka terjadilah kerusakan lingkungan dan penurunan kondisi dan fungsi hidrologis dari suatu daerah aliran sungai.

$\begin{array}{llr}\text { Penurunan } & \text { fungsi } & \text { hidrologis } \\ \text { menyebabkan } & \text { terjadinya } & \text { bencana }\end{array}$ hidrologis, berkurangnya kemampuan daerah aliran sungai dalam menyimpan air dan berkurangnya kemampuan daerah aliran sungai dalam menstabilkan keberadaan air. Gejala penurunan fungsi hidrologis daerah aliran sungai ini dapat dijumpai di beberapa wilayah/ kawasan di Indonesia, antara lain di Pulau Jawa, Pulau Sumatera dan Pulau Kalimantan.

Adanya penurunan fungsi lahan dan penurunan kualitas lingkungan kurang mendapat perhatian khusus baik dari pemerintah maupun masyarakat sekitarnya, oleh karena itu perlu adanya upaya peningkatan kualitas lingkungan berbasis interactive participation.

Interactive Participation merupakan salah bentuk tipe partisipasi masyarakat dalam bidang studi pembangunan. Partisipasi masyarakat diperlukan 
karena masyarakat adalah pihak yang terkena dampak langsung apabila terjadi penurunan kualitas lingkungan. Pengertian interactive participation adalah partisipasi rakyat dalam analisis bersama mengenai pengembangan perencanaan aksi dan pembentukan atau penekanan lembaga local [2].

Dalam interactive participation, partisipasi dinilai sebagai hak masyarakat, bukan dinilai sebagai cara untuk mencapai target suatu kegiatan saja. Pengambilan keputusan dilakukan oleh kelompok dan bersifat lokal, dimana kelompok mempunyai hak untuk menentukan bagaimana ketersediaan sumber daya lingkungan yang digunakan, sehingga diharapkan kelompok tersebut mempunyai wewenang untuk ikut terlibat dalam menjaga potensi yang ada di lingkungannya.

\section{Ruang Lingkup Penelitian}

Di Pulau Jawa terdapat banyak daerah aliran sungai yang mampu mendukung dan memenuhi kebutuhan air masyarakat sekitarnya, namun mengingat luasnya wilayah Pulau Jawa dan pertimbangan faktor ketergantungan masyarakat terhadap daerah aliran sungai tertentu, sehingga wilayah studi pada penelitian ini dibatasi di daerah aliran sungai (DAS) Solo.

DAS Solo merupakan DAS terluas di Wilayah Sungai Bengawan Solo. DAS Solo meliputi Sub DAS Solo Hulu, Sub DAS Kali Madiun dan Sub DAS Solo Hilir. Dengan adanya otonomi daerah, maka bentangan DAS Solo yang hulunya berada di Kabupaten Pacitan dan hilirnya berada di Kabupaten Gresik, pada akhirnya secara administratif terbagi pada 2 wilayah propinsi, yaitu propinsi Jawa Tengan dan propinsi Jawa Timur. Berikut ini adalah peta batas administrasi DAS Solo yang diperoleh dari Balai Penelitian Teknologi Kehutanan Pengelolaan DAS,

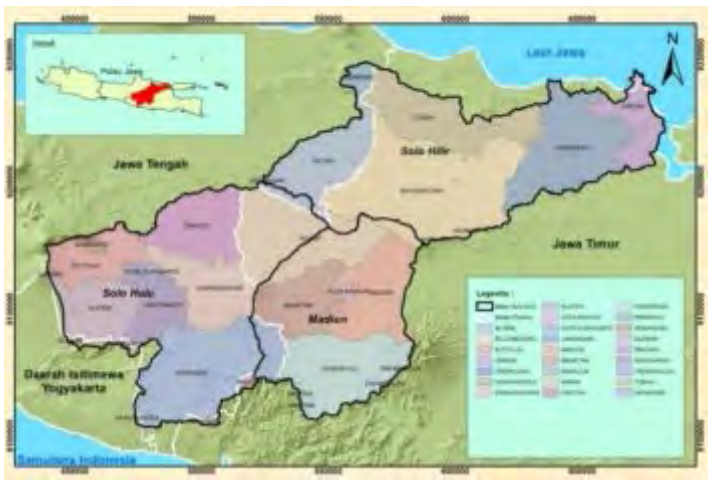

Gambar 1.2. Peta Batas Administrasi Daerah Aliran Sungai (DAS) Solo

(Sumber : Balai Penelitian Teknologi Kehutanan Pengelolaan DAS)

Keterlibatan masyarakat sebagai subyek penelitian juga dibatasi dan difokuskan pada tingkat masyarakat dan kelurahan. Untuk tingkat masyarakat dan kotamadya ke atas tetap diperlukan sebagai tambahan informasi dalam proses analisis penelitian. Kemudian tipe partisipasinya difokuskan pada interactive participation.

\section{Tujuan dan Manfaat Penelitian}

Penelitian ini mempunyai beberapa tujuan, antara lain:

- Mengemukakan permasalahan daerah aliran sungai yang mengakibatkan adanya penurunan kualitas lingkungan DAS Solo.

- Mengkondisikan masyarakat agar menjadi kekuatan utama dalam peningkatan kualitas lingkungan DAS Solo.

- Memberikan informasi kepada pemerintah mengenai 
pemberdayaan masyarakat yang sesuai dengan kondisi setempat.

Penelitian ini juga mempunyai beberapa manfaat, antara lain:

- Memperoleh informasi mengenai permasalahan daerah aliran sungai yang mengakibatkan adanya penurunan kualitas lingkungan DAS Solo.

- Meningkatkan peran serta masyarakat khususnya pada tingkatan interactive participation, dimana masyarakat merupakan kekuatan utama (subyek) dalam peningkatan kualitas lingkungan DAS Solo.

- Memberikan informasi kepada pemerintah mengenai pemberdayaan masyarakat yang sesuai dengan kondisi setempat.

\section{METODE PENELITIAN}

Metode penelitian bersifat deskriptif kualitatif, sehingga dalam analisis permasalahan dan pembuatan model yang merupakan hasil akhir penelitian ini akan didasarkan pada analisis kualitatif.

Tahap penelitian yang dilakukan dimulai dari penentuan batas wilayah penelitian dan identifikasi masalah, kemudian dilanjutkan proses pengumpulan data. Pengumpulan data meliputi data primer dan data sekunder. Setelah data terpenuhi, dilakukan proses analisis yang menghasilkan sebuah rancangan sederhana mengenai model pemberdayaan masyarakat berbasis interactive participation.

\section{Proses Pengumpulan Data}

Data primer diperoleh dengan pengamatan langsung di lapangan, dengan melakukan focus group discussion (FGD), dengan melakukan wawancara mendalam terhadap tokoh kunci (indepth interview) dan dengan melakukan wawancara terstruktur (structured interview). Tujuan dari wawancara terstruktur adalah untuk mengarahkan hasil wawancara sesuai dengan tujuan penelitian. Pemilihan responden menggunakan metode random sampling. Responden terpilih diutamakan sudah berkeluarga, namun tanpa membedakan jenis kelamin.

Data primer yang diperoleh antara lain : data kualitas lingkungan (pemanfaatan lahan, kualitas air, dll), data kondisi masyarakat di sekitar DAS Solo (kondisi pendidikan, sosial, ekonomi, dst). Data Sekunder yang diperoleh antara lain: literatur terkait dengan kualitas lingkungan dan pemberdayaan masyarakat dalam pengembangan dan pengelolaan DAS Solo, Peraturan Pemerintah yang terkait dengan penelitian ini dan Program Pemerintah yang terkait dengan peningkatan kualitas lingkungan DAS Solo.

\section{Proses Analisis Data}

Untuk mewujudkan tercapainya tujuan penelitian, proses analisa data yang dilakukan harus berdasarkan permasalahan yang sudah diidentifikasi sebelumnya, yaitu peningkatan kualitas lingkungan daerah aliran sungai Solo berbasis interactive participation. Proses analisis data dalam penelitian ini dilakukan secara holistik melalui beberapa tahapan sebagai berikut :

- Pengelompokkan data sesuai kebutuhan analisis,

- Analisis data secara deskriptif kualitatif, sesuai dengan pemilihan metode penelitian 
yang sudah ditentukan sebelumnya.

\section{Diagram Alir Penelitian}

Secara garis besar metode yang digunakan dalam penelitian dapat dijelaskan pada gambar diagram alir penelitian berikut ini,

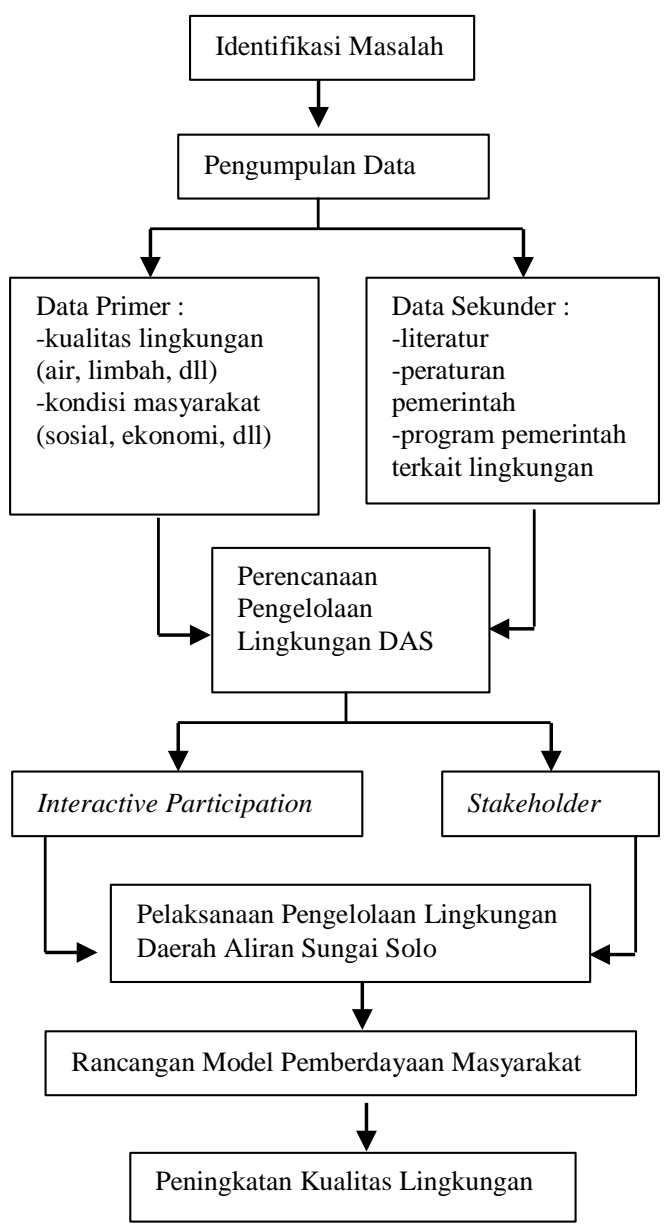

Gambar 1.3. Diagram Alir Penelitian

\section{HASIL dan PEMBAHASAN}

\section{Kondisi Lingkungan di Daerah Aliran Sungai (DAS) Solo}

Berdasarkan Keputusan Menteri Kehutanan Republik Indonesia No: SK.328/Menhut-II/2009, DAS Solo merupakan salah satu dari 35 DAS di Jawa Tengah dan Jawa Timur, DAS Solo adalah DAS lintas propinsi yang pada saat ini berada dalam kondisi kritis [3].

Kondisi kritis menggambarkan banyak terjadi bencana hidrologis di DAS tersebut, antara lain: banjir, tanah longsor, penurunan kualitas air, kekeringan, dan perubahan fungsi tata guna lahan. Sistem lahan di daerah aliran sungai Solo mayoritas didominasi oleh dataran, berikut ini adalah peta sistem lahan DAS Solo yang diperoleh dari Balai Penelitian Teknologi Kehutanan Pengelolaan DAS,

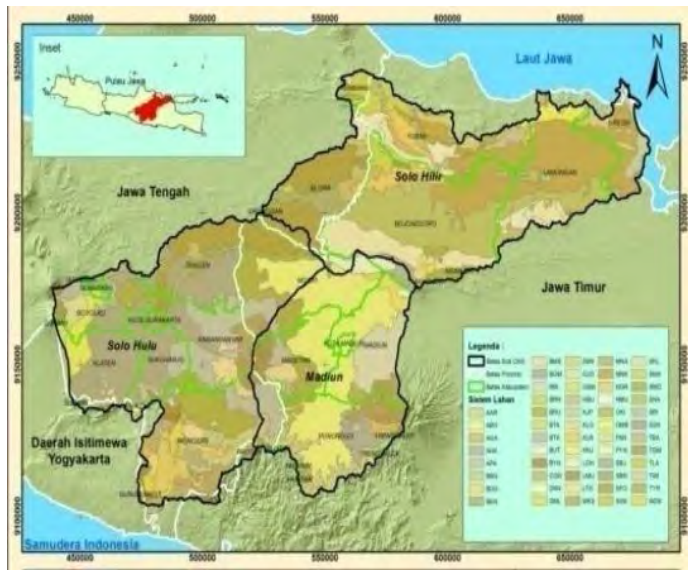

Gambar 1.4. Peta Sistem Lahan Daerah Aliran Sungai (DAS) Solo

(Sumber : Balai Penelitian Teknologi Kehutanan Pengelolaan DAS)

Pemanfaatan lahan DAS Solo mengalami perubahan, saat ini lahan didominasi sawah (irigasi dan tadah hujan), kebun, tegalan dan permukiman penduduk. Kualitas air sungai Solo juga menurun, hasil uji kualitas air menunjukkan melebihi ambang batas dalam fungsi perikanan, sehingga sekarang ini air hanya dapat digunakan untuk irigasi pertanian dan perkebunan.

Perubahan penggunaan lahan dapat menurunkan kualitas air, meningkatkan debit air permukaan, meningkatkan frekuensi air banjir, meningkatkan aliran air dua kali lebih besar dari hutan alam, menyebabkan hilangnya bahan material 
dan mengakibatkan penurunan air tanah [4].

Kriteria curah hujan tidak rentan banjir jika besarnya curah hujan harian kurang dari $20 \mathrm{~mm}$, agak rentan banjir jika berkisar antara 21-40 mm, sedang jika hujannya berkisar antara 41-75 mm, rentan banjir jika berkisar antara 76-150 $\mathrm{mm}$, dan sangat rentan jika curah hujannya melebihi $150 \mathrm{~m}$ [5].

Berdasarkan hasil analisa, curah hujan maksimum harian DAS Solo sekitar 73 $\mathrm{mm} /$ hari (sedang) sampai sangat tinggi $186 \mathrm{~mm} /$ hari, dan didukung oleh bentuk lahan yang relatif datar, sehingga dapat disimpulkan bahwa DAS Solo termasuk daerah rawan banjir. Berikut ini adalah prosentase daerah rawan banjir di DAS Solo.

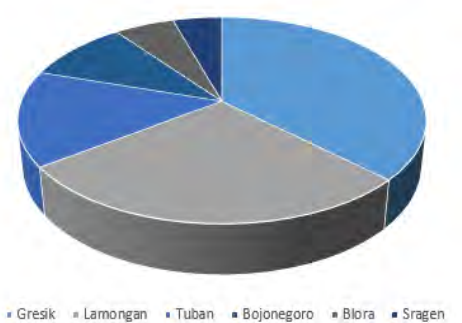

Gambar 5. Prosentase Daerah Rawan Banjir di DAS Solo

\section{Kondisi Masyarakat di Daerah Aliran Sungai (DAS) Solo}

Berdasarkan informasi dari Badan Pusat Statistik (2019), jumlah penduduk paling tinggi ada di Kabupaten Klaten, kepadatan penduduk tertinggi ada di Kota Surakarta dan wilayah yang paling luas berada di Kabupaten Bojonegoro [6][7].

Berdasarkan data dari Bank Indonesia (2017), hanya terdapat 5 daerah yang pertumbuhan ekonominya cukup tinggi, yaitu berada di atas pertumbuhan ekonomi Indonesia (sekitar 6,5\%). Adapun 5 daerah tersebut antara lain Kabupaten Bojonegoro, Karanganyar, Lamongan, Gresik dan Kota Madiun [8]. Sedangkan untuk pendapatan perkapita tertinggi ada di Kabupaten Gresik. Berikut ini adalah diagram prosentase pendapatan perkapita masing-masing daerah yang masuk kawasan DAS Solo berdasarkan analisis data sekunder.

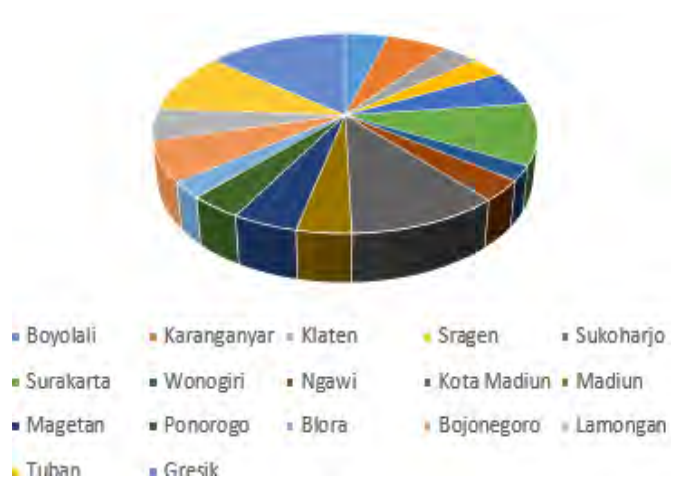

Gambar 1.6. Prosentase Pendapatan Perkapita Kabupaten di DAS Solo

(Sumber : Badan Pusat Statistik)

Berdasarkan informasi dari Badan Pusat Statistik, tingkat pendidikan penduduk di DAS Solo mengalami peningkatan tiap tahunnya. Semakin tinggi tingkat pendidikan yang mereka miliki maka akan semakin tinggi tingkat kesadaran dalam ikut menjaga kualitas lingkungan. Berikut ini adalah prosentase nilai indeks kesadaran masyarakat dalam menjaga kualitas lingkungan ditinjau dari tingkat pendidikan masyarakat DAS Solo.

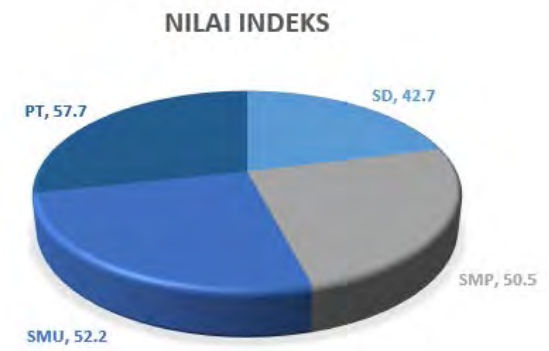

\footnotetext{
Gambar 6. Prosentase Nilai Indeks

Kesadaran Masyarakat Berdasarkan Tingkat Pendidikan
}

(Sumber : Badan Pusat Statistik)

Adapun keterangan nilai indeks pada gambar tersebut dapat dijelaskan sebagai berikut: masyarakat tamat sekolah dasar (SD) mempunyai nilai indeks sebesar 
42,7\% (rendah), masyarakat tamat SLTP sebesar 50,5\% (cukup tinggi), masyarakat tamat SLTA sebesar 53,2\% (tinggi) dan masyarakat tamat akademi/ perguruan tinggi memiliki nilai indeks sebesar $57,7 \%$ termasuk ke dalam kategori memiliki kesadaran sangat tinggi dalam upaya peningkatan kualitas lingkungan di DAS Solo.

\section{Model Pemberdayaan Masyarakat Berbasis Interactive Participation}

Tingkat pendidikan masyarakat di DAS Solo tergolong baik, sehingga dipilihlah model pemberdayaan masyarakat berbasis interactive participation, dimana masyarakat sekitar dilibatkan dalam proses perencanaan pembangunan. Pada tipe ini, kelompok masyarakat dapat dibentuk bersamasama dengan stakeholder dan lembaga terkait yang mempunyai tugas untuk mengendalikan dan memutuskan semua permasalahan yang terjadi di tingkat lokal.

Besarnya kesempatan masyarakat untuk terlibat langsung menunjukkan bahwa model pemberdayaan yang sesuai dengan interactive participation adalah model Bottom Up. Model yang bersifat bottom up didasarkan pada tindakan merubah perilaku masyarakat dengan menumbuhkan kesadaran melestarikan lingkungan. Berikut ini adalah gambar permodelan bottom up yang sesuai dengan pemberdayaan masyarakat berbasis interactive participation [9]

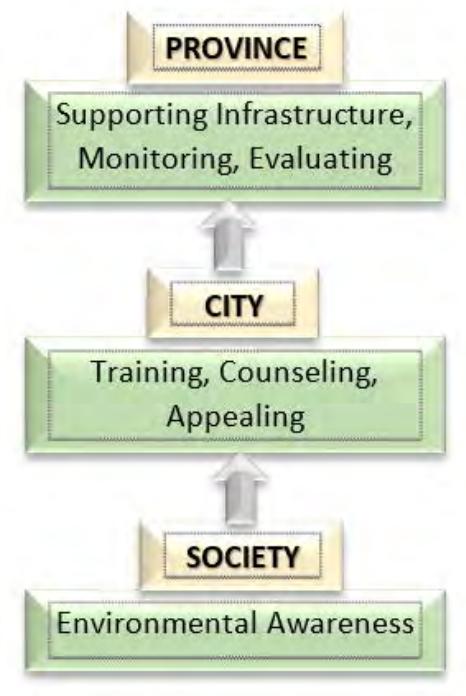

Gambar 7. Model Bottom Up

Perencanaan dengan model Bottom Up ini dilaksanakan secara kolektif, melibatkan unsur governancel stakeholder/ owner yang mengandalkan unsur persuasi (keyakinan atau kepercayaan) dan unsur co-production. Dan berikut ini merupakan argumentasi (berupa penjelasan, pembuktian, alasan, maupun ulasan objektif) mengenai model bottom-up :

- Efektivitas, yaitu keadaan yang ditunjukkan melalui tingkat keberhasilan yang terukur dengan kualitas, kuantitas, dan waktu, sesuai dengan yang telah direncanakan sebelumnya,

- Kinerja (performance, outcome), bukan sekadar hasil seketika dan buruk kualitasnya,

- Social virtue (kearifan sosial),

- Masyarakat diasumsikan sudah paham mengenai hak-hak mereka dan paham mengenai apa yang mereka butuhkan. 


\section{KESIMPULAN}

DAS Solo berada pada kondisi kritis, dimana kondisi tersebut menggambarkan banyaknya bencana hidrologis yang terjadi. Pemanfaatan lahan DAS Solo didominasi sawah (irigasi dan tadah hujan), kebun, tegalan dan permukiman penduduk. Curah hujan maksimum harian DAS Solo sekitar 73 $\mathrm{mm} /$ hari - $186 \mathrm{~mm} /$ hari, didukung oleh bentuk lahan yang relatif datar, sehingga dapat disimpulkan bahwa DAS Solo termasuk daerah rawan banjir.

Dari hasil analisis diperoleh bahwa semakin tinggi tingkat pendidikan maka akan semakin tinggi tingkat kesadaran dalam menjaga kualitas lingkungan. Besarnya kesempatan masyarakat untuk terlibat langsung menunjukkan bahwa model pemberdayaan yang sesuai dengan interactive participation adalah model Bottom Up. Model Bottom Up menumbuhkan kesadaran bersama untuk meningkatkan kualitas lingkungan dan melestarikan lingkungan berdasar asas keberlanjutan dan kemanfaatan.

\section{SARAN}

Perlu dilakukan sosialisasi secara berkala mengenai pentingnya peningkatan kualitas lingkungan, disertai kegiatan yang memerlukan keterlibatan masyarakat secara berkelanjutan. Pada bidang penegakan peraturan dan kegiatan evaluasi monitoring harus berjalan seimbang dan melibatkan seluruh pihak yang terkait dalam upaya peningkatan kualitas lingkungan DAS Solo.

\section{UCAPAN TERIMAKASIH}

Terima kasih kepada Balai Penelitian Teknologi Kehutanan Pengelolaan Daerah Aliran Sungai, Direktorat
Kehutanan dan Konservasi Sumber Daya Air, Pemerintah dan Masyarakat DAS Solo, serta seluruh pihak yang telah membantu terselesaikannya penelitian ini.

\section{DAFTAR PUSTAKA}

[1] Peraturan Pemerintah No.33 Tahun 1970 tentang Perencanaan Hutan. 1970.

[2] M. Hobley, "Participatory Forestry: The Process of Change in India and Nepal. In Rural Development Forestry Study Guide 3. London: Rural Development Forestry Network," Press, University, 1996.

[3] Keputusan Menteri Kehutanan Republik Indonesia No: SK.328/Menhut-II/2009. 2009.

[4] R. Setyowati, "Studi Literatur Pengaruh Penggunaan Lahan Terhadap Kualitas Air,” J. IlmuIlmu Tek., vol. 12, no. 1, pp. 7-15, 2016.

[5] D. Paimin, "Sidik Cepat Degradasi Sub Daerah Aliran Sungai (Sub DAS). Bogor: Badan Penelitian dan Pengembangan Kehutanan,” 2010.

[6] BPS, "Jawa Tengah dalam Angka 2019,” 2019.

[7] BPS, "Jawa Timur dalam Angka 2019,” 2019.

[8] Bank Indonesia, "Laporan Perekonomian Indonesia Tahun 2017 Jakarta,” 2017.

[9] D. Susilowati, "Peran Serta Masyarakat dalam Meningkatkan Kualitas Lingkungan Daerah Aliran Sungai Ciliwung," J. PoliTeknologi, 2012. 